\title{
TINGKAH LAKU HARIAN KUSKUS BERUANG (Ailurops ursinus) DI CAGAR ALAM TANGKOKO BATU ANGUS
}

\author{
Pratiwi A.A. Talumepa*, R. S. H. Wungow, Z. Poli, S. C. Rimbing \\ Fakultas Peternakan Universitas Sam Ratulangi Manado 95115
}

\begin{abstract}
ABSTRAK
Penelitian ini bertujuan untuk mendeskripsikan tingkah laku harian Kuskus Beruang (Ailurops ursinus) di Cagar Alam Tangkoko Batu Angus. Penelitian ini diharapkan dapat memberikan infromasi mengenai tingkah laku istirahat, berjalan, makan, grooming dan sosial sebagai variabel utama untuk menidentifikasi aktivitas harian. Penggunaan vegetasi selama tingkah laku harian dimasukan dalam penelitian ini sebagai data penunjang untuk variabel sekunder. Penelitian ini menggunakan metode observasi untuk mengamati langsung dilapangan dan menggunakan teknik instantinous animal sampling. Teknik ini mengamati tingkah laku sebanyak 14 kali dengan 1 jam (60 menit) pengamatan dengan interval 1 menit (60 detik). Hasil penelitian ini menunjukan aktivitas harian Ailurops ursinus didominasi oleh tingkah laku istirahat dengan persentase $56,86 \%$ dari total aktivitas harian yang mana menggunakan 30,5 menit pada pagi hari, 42,6 menit pada siang hari dan 29,2 menit pada sore hari. tingkah laku makan dengan persentase $26,98 \%$ digunakan untuk 17,2 menit di pagi hari, 8 menit di siang hari dan 23,3 menit di sore hari. tingkah laku berjalan dengan persentase $15,11 \%$ digunakan untuk 11,7 menit di pagi hari, 8,7 menit di siang hari dan 6,6 menit pada sore hari. Tingkah laku grooming dengan persentase $0,98 \%$ digunakan 0,5 menit pada pagi hari, 0,7 menit pada siang hari. Tingkah laku sosial dengan
\end{abstract}

\footnotetext{
*Korespondensi (corresponding author):

Email: Thiwie.Talumepa@gmail.com
}

persentase $0,03 \%$ dari total tingkah laku harian yang mana hanya terjadi pada siang hari.

Kata Kunci: Tingkah laku harian, Kuskus Beruang, Cagar Alam Tangkoko Batu Angus

\section{ABSTRACT}

DAILY BEHAVIOUR OF SULAWESI BEAR CUSCUS (Ailurops ursinus) IN TANGKOKO BATU ANGUS NATURE RESERVE. This study aimed to describe dailly behaviour of Sulawesi Bear Cuscus (Ailurops ursinus) in Tangkoko Batu Angus Nature Reserve. This reseach is expected to provide information about inactive, foraging, intake, groom and social behavior of Ailurops ursinus as primary behavior variables of the animal daily activities. The usie of vegetation during animal daily activities were introducted in this research as a secondary variable. This research used obsevation as research method and instantinous animal sampling technique. This method observed Ailurops ursinus behavior three times per day . Each single observe was done in 60 minutes with 60 seconds time interval. Every single observe was replicated 14 times. The result of this research showed that the daily behaviour of Ailurops ursinus was dominated by inactive behaviour with 56.86 percents consisted of 30.5 minutes were spent in the morning, 42.6 minutes at noon and 29.2 minutes in the afternoon. Intake behaviour took times of 26.98 percents consisted of 17.2 minutes were spent in the morning, 8 minutes at noon and 23.3 minutes in the afternoon. The foraging behaviour 
took times of 15.11 percents consisted of 11.7 minutes were spent in the morning, 8.7 minutes at noon and 6.6 minutes in the afternoon. Groom activity spent times of $0.98 \%$ consisted of 0.5 minutes spent in the morning, 0.5 minutes at noon and 0.7 minutes in the afternoon. Social behaviour took spent time of $0.03 \%$ of total daily behaviour spent only at noon.

Keywords : Daily behaviour, Sulawesi Bear Cuscus (Ailurops ursinus), Tangkoko Batu Angus Nature Reserve

\section{PENDAHULUAN}

Kuskus beruang (Ailurops ursinus) jenis Marsupialia yang tergolong dalam famili Phalageridae dan merupakan famili dengan penyebaran cukup luas di antara jenis Marsupialia lainnya. Kuskus beruang merupakan salah satu dari dua jenis mamalia berkantung, endemik Pulau Sulawesi yang dapat ditemui di Cagar Alam Tangkoko Batu Angus, yang merupakan salah satu kawasan konservasi yang ada di Sulawesi Utara.

Kuskus beruang merupakan salah satu jenis satwa mamalia endemik yang dilindungi berdasarkan SK Menteri Kehutanan tanggal 8 September 1992 nomor $882 / \mathrm{Kpts} / 11 / 1992$ yang terancam populasinnya. Dalam laporan Wildlife Conservation Society (WCS) tahun 2005, menyatakan bahwa populasi kuskus beruang cenderung menurun selama beberapa tahun terakhir. Dari hasil penelitian yang dilakukan tahun 1999 oleh WCS memperkirakan jumlah populasi kuskus beruang sebanyak 66 ekor $/ \mathrm{km}^{2}$ dan pada tahun 2008 dari hasil penelitian Repi populasi kuskus beruang menurun menjadi 53 ekor $/ \mathrm{km}^{2}$.

Kuskus beruang merupakan satwa arboreal yang hidup di tajuk pohon dan jarang terlihat berjalan diatas tanah. Daundaun merupakan komponen utama dalam pakan kuskus beruang, sehingga satwa ini lebih menyukai tempat yang ditumbuhi pohon-pohon sebagai habitatnya (Dwiyahreni,1995). Kuskus beruang biasanya hidup di hutan dataran rendah pada ketinggian 0-400 meter diatas permukaan laut. Satwa ini jarang ditemui di hutan primer yang mempunyai ketinggian lebih dari 400 meter diatas permukaan laut (Mambuhu, 2005).

\section{Internasional Union Conservation} of Nature (2008) yang menjadi organisasi yang banyak melakukan usaha konservasi flora dan fauna di dunia memasukan kuskus beruang dalam redlist (buku merah) dan tergolong sebagai satwa vulnerable (terancam), karena semakin berkurangnya populasi dari kuskus beruang. 
Provinsi Sulawesi Utara dengan tingkat konsumsi satwa liar (bushmeat) yang sangat tinggi, masih kurang mengenal kuskus beruang sebagai satwa endemik Sulawesi yang dilindungi dibandingkan dengan satwa yang dilindungi lainnya seperti yaki (Macaca nigra) dan tarsius (Tarsius spectrum) sehingga potensi ancaman manusia terhadap kuskus beruang sangat tinggi, bahkan usaha pelestarian kuskus beruang di habitat asli saat ini masih terus mengalami kerusakan habitat akibat aktivitas manusia seperti ilegal logging, penambangan liar, perburuan dan kebakaran hutan.

Salah satu strategi yang tepat untuk diterapkan dalam meningkatkan populasi dan pelestarian satwa adalah dengan memahami aktivitas harian (Alikodra, 2002), sehingga aktivitas harian kuskus beruang di Cagar Alam Tangkoko sangat penting untuk dipelajari, karena satwa ini merupakan satwa arboreal yang sulit ditemui serta tingkat kunjungan manusia dan eksploitasi hutan dapat berpengaruh terhadap kondisi satwa ini. Oleh karena itu dengan mengetahui tingkah laku kuskus beruang dapat memberikan informasiinformasi penting dalam menentukan strategi yang tepat untuk pengelolaan satwa liar dalam rangkaian peningkatan populasi dan usaha pelestariannya.
Dan berdasarkan hal-hal diatas telah dilakukan penelitian untuk mengetahui tingkah laku harian kuskus beruang sebagai informasi penting untuk dipakai dalam penentuan strategi untuk peningkatan populasi dan pelestariannya.

\section{MATERI DAN METODE PENELITIAN}

Penelitian ini dilakukan di Cagar Alam Tangkoko Batu Angus yang terletak di kota Bitung provinsi Sulawesi Utara, selama 3 bulan dari tanggal 1 November 2014 sampai tanggal 28 Februari 2015. Penelitian ini menggunakan beberapa ekor kuskus beruang (Ailurops ursinus) yang teramati sebagai materi penelitian.

\section{Metode Penelitian}

Penelitian ini menggunakan metode observasi yang mengharuskan pengamatan langsung dilokasi penelitian dimana materi penelitian berada. Dalam melakukan penelitian ini, telah dilakukan studi pendahuluan sebelum melakukan pengambilan data. Prosedur pengamatan menggunakan teknik Instantinous Animal Sampling.

\section{Prosedur Penelitian}

Teknik Instantinous animal sampling (Altmann, 1974) digunakan sebagai prosedur pengamatan tingkah laku. 
Pengamatan dilakukan sebanyak 14 kali pengulangan, yang dilakukan sebanyak 3 kali per hari (pagi, siang dan sore), dengan lama waktu pengambilan data 60 menit (1 jam) dengan interval 1 menit setiap pengambilan data sheet. Dengan demikian maka total waktu pengambilan data berjumlah 2520 menit (42 jam).

\section{Variabel Penelitian}

Variabel yang diamati pada penelitian ini adalah tingkah laku istirahat (saat berhenti beraktivitas/diam dan tidur), tingkah laku makan (saat memakan makanan), tingkah laku berjalan (saat berjalan berpindah pohon), tingkah laku grooming (saat membersihkan diri sendiri atau objek penelitian lainnya), tingkah laku sosial (saat melakukan interaksi dengan objek penelitian lainnya).

\section{Analisis Data}

Data yang diperoleh pada hasil pengamatan ditabulasi selanjutnya disajikan secara deskriptif dan etogram dengan penguraian sebagai berikut :

- Deskriptif, yaitu penguraian dan penjelasan mengenai gambaran umum hasil pengamatan secara langsung berdasarkan tabulasi data yang diperoleh dari pengambilan data. Penjelasan dalam penelitian ini akan meliputi tingkah laku berdasarkan variable penelitian sehingga dapat menjadi parameter pada masingmasing variable. Pembahasan secara deskriptif akan dilakukan dengan melihat hasil tabulasi data mengenai presentase tingkah laku yang menggunakan rumus :

Presentase tingkah laku : $\frac{\text { jumla } h \text { waktu yang digunakan }}{\text { jumla } h \text { seluru } h \text { waktu yang digunakan }} \quad \mathrm{X}$ 100\% (Altman, 1974)

- Etogram, yaitu penggambaran hubungan antara variable yang diamati agar dapat menyimpulkan seluruh analisis deskriptif yang didapatkan dari seluruh hasil pengamatan.

\section{HASIL DAN PEMBAHASAN}

Kuskus beruang di Cagar Alam Tangkoko paling sering ditemukan pada pohon yang cukup tinggi, kecuali pohon mangga yang memang tidak terlalu tinggi dan kondisi vegetasi yang cukup rapat juga sangat membatasi pengambilan data selama penelitian.

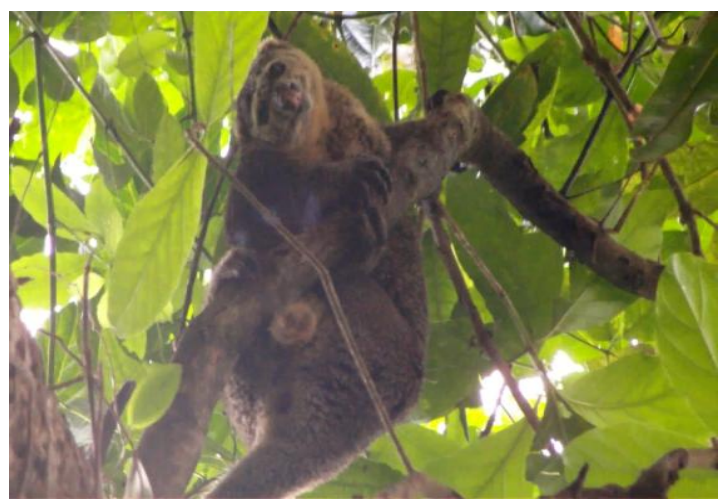


Gambar 1. Kuskus beruang di Cagar Alam Tingkah Laku Istirahat

Waktu istirahat kuskus beruang dapat terjadi pada pagi hari, siang hari dan sore hari. Hasil pengamatan menunjukkan bahwa aktivitas istirahat kuskus beruang sangat tinggi. Tingkahlaku istirahat kuskus beruang dapat dilihat pada gambar dibawah.

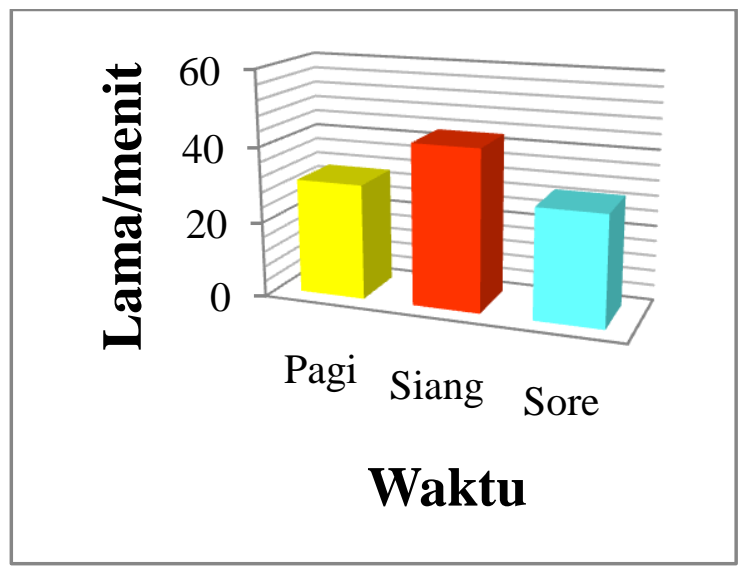

Gambar 2. Rataan Waktu Istirahat

Rataan waktu istirahat kuskus beruang pada pagi hari sebesar 30,5 menit $(50,8 \%)$, kemudian siang hari sebesar 42,6 menit $(71 \%)$ dan pada sore hari sebesar 29,2 menit $(48,6 \%)$ dan secara keseluruhan waktu yang dipakai kuskus beruang untuk istirahat sebesar $56,86 \%$.

Tingkah laku istirahat kuskus beruang biasanya dilakukan setelah makan. Dimana dalam melakukan tingkah laku istirahat kuskus beruang berdiam diri dan terkadang kuskus beruang menggerakkan ekornya pada saat istirahat.
Tangkoko

\section{Tingkah Laku Makan}

Tingkah laku makan kuskus beruang merupakan faktor utama yang membuat kuskus beruang sering melakukan perpindahan tempat atau bergerak. Tingkahlaku makan kuskus beruang akan selalu diikuti dengan perpindahan tempat dalam satu pohon atau ke pohon lainnya karena kuskus beruang selalu memilih makanan yang akan dimakan. Rataan tingkah laku makan kuskus beruang sebagai berikut

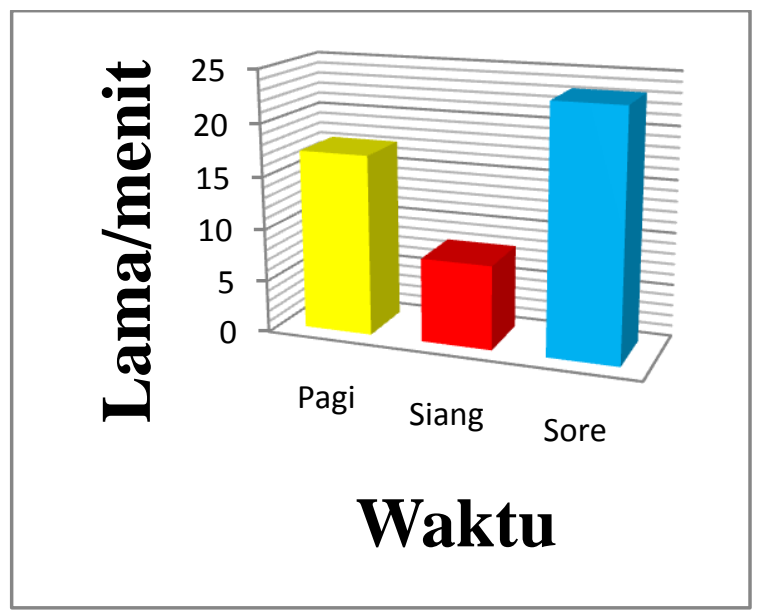

Gambar 3. Rataan waktu makan

Rataan tingkah laku makan kuskus beruang pada pagi hari sebesar 17,2 menit $(28,6 \%)$, siang hari sebesar 8 menit $(13,3 \%)$ dan pada sore hari sebesar 23,3 menit $(38,8 \%)$ dengan persentase tingkah laku makan yang dilakukan oleh kuskus beruang dalam satu hari sebesar 26,99\% .

Dari hasil penelitian didapati bahwa 
tingkah laku makan kuskus beruang

Tingkah laku makan yang di dominasi pada sore hari kemungkinan karena kuskus beruang menyimpan asupan cadangan makanan, karena pada malam hari kuskus beruang tidak melakukan aktivitas atau istirahat.

Bagian tubuh kuskus beruang yang menjadi indikator awal untuk melihat tingkah laku makan kuskus beruang adalah tangan dan hidung. Kuskus beruang akan memilih makanan dengan cara memegang makanan dengan tangan dan mencium makanan tersebut dalam proses untuk memilih makanan, hal tersebut kemungkinan dilakukan untuk mengetahui apakah daun atau buah tersebut sudah bisa di makan atau belum. Dan ketika kuskus beruang merasa kalau buah atau daun tersebut dapat dimakan kuskus beruang akan langsung memakannya.

tertinggi terjadi pada sore hari.

Dari hasil pengamatan yang didapati di lapangan kuskus beruang lebih sering memakan buah-buahan seperti buah mangga dibandingkan dengan makanan pokoknya yang diketahui yaitu daun muda. Jenis pohon yang dimanfaatkan oleh kuskus beruang utuk makan atau beristirahat. Keadaan pohon dan posisi sangat mempengaruhi pilihan makanan kuskus beruang, karena biasanya kuskus beruang akan memilih pohon yang besar dan kuat. Lokasi pohon yang berdekatan juga menjadi pilihan ideal kuskus beruang untuk mempermudah perpindahan tempat. Rataan jenis pohon yang sering di manfaatkan oleh kuskus beruang dapat dilihat pada Tabel 1 di bawah ini :

Tabel 1. Rataan Jenis Pohon

\begin{tabular}{lcccc}
\hline \multirow{2}{*}{ Waktu } & \multicolumn{4}{c}{ Jenis Pohon } \\
\cline { 2 - 5 } & $\begin{array}{c}\text { Terminalia } \\
\text { catappa }\end{array}$ & $\begin{array}{c}\text { Dracontomelon } \\
\text { dao }\end{array}$ & $\begin{array}{c}\text { Garuga } \\
\text { floribunda }\end{array}$ & Mangifera indica \\
\hline Pagi & 1 & 2 & 4 & 7 \\
Siang & - & 1 & 2 & 11 \\
Sore & - & 7 & 4 & 3 \\
Total & 1 & 10 & 10 & 21 \\
Rataan $(\%)$ & 2,38 & 23,80 & 23,80 & 50 \\
\hline
\end{tabular}




\section{Tingkah Laku Berjalan}

Tingkah laku berjalan kuskus beruang biasanya dilakukan saat akan berpindah dari pohon yang satu ke pohon yang lain. Tingkah laku berjalan kuskus beruang dilakukan dengan cara menggunakan kedua tangan dan kaki serta ekornya. Ekor kuskus beruang paling sering digunakkan untuk menjaga keseimbangan atau menggantung. Tangan dan kaki kuskus beruang digunakan untuk berpindah tempat dengan cara berjalan atau mengambil dahan yang lainnya (saat berpindah pohon). Rataan waktu berjalan kuskus beruang dapat dilihat pada gambar dibawah ini .

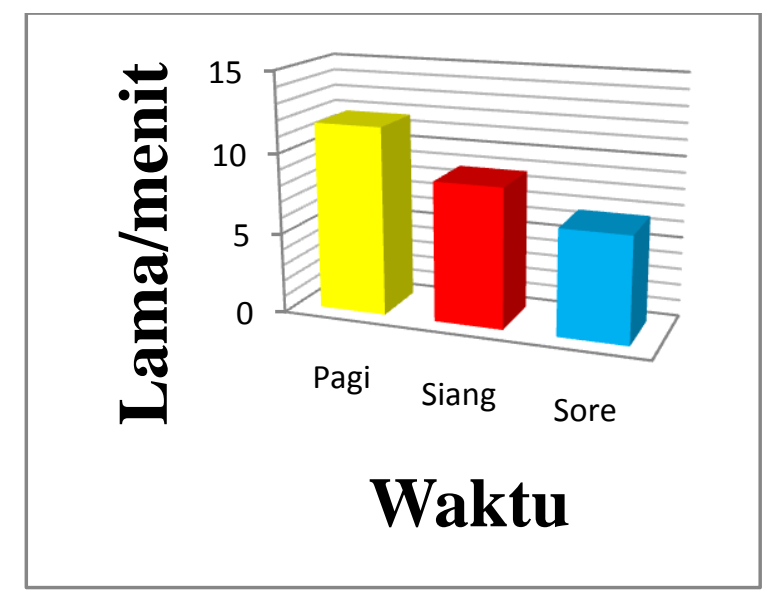

Gambar 4. Rataan waktu berjalan

Dari hasil pengamatan didapati bahwa tingkah laku berjalan kuskus beruang pada pagi hari sangat tinggi sebesar 11,7 menit $(19,5 \%)$, pada siang hari sebesar 8,7 menit $(14,5 \%)$ dan pada sore hari 6,6 menit (11\%) dan total keseluruhan tingkah laku berjalan yang dilakukan sebesar $15,11 \%$. Biasanya kuskus beruang akan berjalan berpindah tempat untuk mencari makanan, sehingga sering mencari pohon yang menyediakan makanan. Faktor lain yang membuat kuskus beruang melakukan tingkah laku berjalan adalah untuk mencari tempat beristirahat. Kuskus beruang melakukan tingkah laku berjalan dengan menggunakan kedua kaki dan tanggannya serta ekornya. Ekor kuskus beruang dipakai ketika kuskus beruang berjalan dan akan berpindah pohon dan jarak antara pohon yang satu dengan yang lain tidak dapat dijangkau oleh tangan dan kakinya, kuskus beruang akan melilitkan ekornya di cabang pohon dan tangannya akan menggenggam cabang pohon yang lain.

\section{Tingkah Laku Grooming}

Grooming merupakan cara spontan yang dilakukan dengan interval waktu 2-3 menit. Kuskus beruang dapat menunjukkan perilaku grooming ketika merasa tidak nyaman atau adanya gangguan pada daerah tubuhnya. Tingkah laku grooming pada kuskus beruang terjadi terjadi pada pagi, siang dan sore hari. 


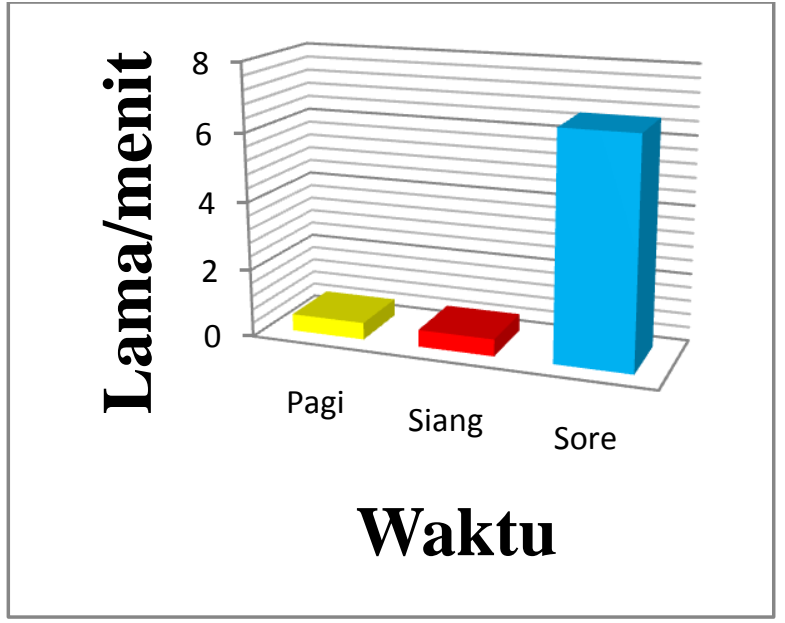

Gambar 5. Rataan waktu grooming

Dari hasil pengamatan didapati bahwa tingkah laku grooming kuskus beruang pada pagi hari sebesar 0,5 menit $(0,8 \%)$, siang hari sebesar 0,5 menit $(0,8 \%)$ dan pada sore hari sebesar 0,7 menit $(1,1 \%)$ dan secara keseluruhan dalam satu hari kuskus beruang menghabiskan waktu untuk grooming sebesar $1 \%$. Tingkah laku grooming kuskus beruang biasanya dilakukan pada satwa itu sendiri (autogrooming).

Grooming pada kuskus beruang terjadi dalam dua hal, grooming dan auto grooming. Auto grooming dilakukan dengan cara kuskus beruang melakukan aktvitas grooming dengan menggaruk menggunakan tangan, kaki atau membersihkan tubuh dengan mulut dan ekor digunakan untuk bertahan pada pohon. Grooming yang dilakukan oleh anggota kelompok lain hanya menggunakan tangan dan mulut.

\section{Tingkah Laku Sosial}

Tingkah laku sosial sangat jarang terjadi pada kuskus beruang karena kuskus beruang merupakan satwa solitare. Tetapi dari hasil pengamatan satwa ini dapat dijumpai secara berkelompok antara dua sampai tiga ekor kuskus beruang yang terdiri dari jantan dewasa, betina dewasa dan anak. Hal tersebut yang membuat adanya tingkah laku sosial pada kuskus beruang. Tingkah laku sosial kuskus beruang dapat dilihat pada gambar dibawah ini.

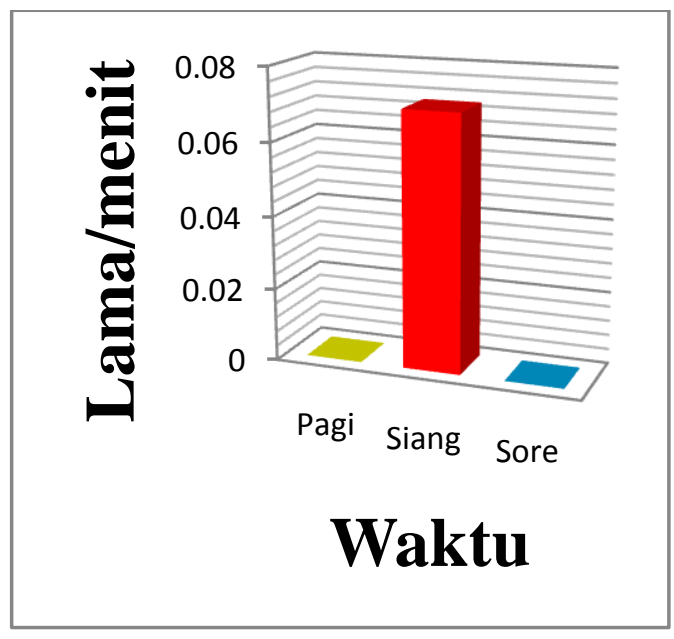

Gambar 6. Rataan waktu sosial

Dari gambar diatas dapat dilihat bahwa tingkah laku sosial dari kuskus beruang pada pagi dan sore hari tidak ditemukan tingkah laku sosial dari kuskus beruang dan pada siang hari tingkah laku kuskus beruang sebesar 0,07 menit $(0,11 \%)$ dan persentase keseluruhan dari tingkah laku sosial sebesar 0,04\%. Tingkah laku sosial kuskus beruang 
dilakukan dengan cara berinteraksi bermain, memeluk dan biasanya diikuti dengan grooming.

Dari hasil pengamatan yang didapati dilapangan tingkah laku sosial kuskus beruang biasanya terjadi antara betina dan anak, dimana kuskus beruang betina biasanya akan mengeluarkan anaknya dari dalam kantung kemuadian kuskus beruang betina membersihkan tubuh anaknya menggunakan kedua tangannya, setelah selesai membersihkan kuskus beruang akan langsung meletakkan kembali anaknya kedalam kantung . Tingkah laku sosial kuskus beruang terjadi pada lokasi pohon yang tinggi. Kemungkinan hal tersebut terjadi disaat kuskus beruang merasa tidak ada ancaman atau merasa aman dari dari satwa lainnya.

\section{KESIMPULAN}

Dari hasil pengamatan di lapangan dapat disimpulkan bahwa tingkah laku harian dari kuskus beruang meliputi tingkah laku istirahat, tingkah laku makan, tingkah laku berjalan, tingkah laku grooming dan tingkah laku sosial. Dimana dari hasil yang di dapat bahwa :

- Tingkah laku istirahat kuskus beruang merupakan tingkah laku yang paling sering dan paling lama dilakukan.
- Dalam tingkah laku makan kuskus beruang akan memanfaatkan sumber makanan yang ada di sekitarnya seperti buah mangga dan daun muda.

- Kuskus beruang melakukan tingkah laku berjalan ketika akan berpindah pohon untuk tempat istirahat, mencari makan dan saat merasa terancam.

- Tingkah laku grooming kuskus beruang kebanyakan melakukan autogrooming dan jarang sekali terlihat grooming pada kuskus beruang lainnya.

- Tingkah laku sosial kuskus beruang lebih banyak terjadi antara kuskus beruang betina dan anaknya.

\section{DAFTAR PUSTAKA}

Alikodra, H.S. 2002. Teknik Pengelolaan Satwa Liar. Fakultas Kehutanan. IPB. Bogor

Altman, J. 1974. Observational Study Of Behavior sampling Method. Nasional Academy Press. Washington DC.

Dwiyahreni, A. 1995. Diet and Activity Of The Bear Cuscus (Ailurops ursinus), In North Sulawesi, Indonesia. Faculty of Mathematics and sciences, University of Indonesia.

International Union Conservation of Nature, 2008. The IUCN Redlist of Threatened Species. http//www.IUCNredlist.org.html. Diunduh tahun 2013 
Repi, T. 2008. Perkiraan Kepadatan Populasi Kuskus Beruang (Ailurops ursinus) Di Cagar Alam Tangkoko. Skripsi. Fakultas Peternakan Universitas Sam Ratulangi. Manado

Wildlife Conservation Society. 1999. Cagar Alam Tangkoko-Duasudara Sulawesi Utara, Indonesia, Survey Biologi, Patroli, Monitoring Dan Rekomendasi Pengelolaan. Wildlife Conservation SocietyIndonesia Program Manado
2005. Cagar Alam Tangkoko-Duasudara Sulawesi Utara, Indonesia, Survey Biologi, Patroli, Monitoring Dan Rekomendasi Pengelolaan. Wildlife Conservation SocietyIndonesia Program Manado 